\title{
Stefan Chwin
}

\section{Grzechy Gombrowicza przeciwko wolności. O projekcie etycznym wpisanym w Ferdydurke}

\begin{abstract}
Chwin Stefan, Grzechy Gombrowicza przeciwko wolności. O projekcie etycznym wpisanym w "Ferdydurke" [Gombrowicz's sins against freedom. On the ethical project presented in Ferdydurke]. "Przestrzenie Teorii” 20. Poznań 2013, Adam Mickiewicz University Press, pp. 11-27. ISBN 978-83-232-2654-3. ISSN 1644-6763.

Gombrowicz's way of thinking about freedom changed over years. He did not simply follow the ideas formulated in the 1930s. In the world presented in Ferdydurke Gombrowicz described the ontological foundations of freedom as significantly weaker than the ontological foundations of enslavement. The structure of this world was based on a strong juxtaposition of the protagonist as a lone "partisan of freedom" who feels uneasy about the constraints imposed by Form and the majority of society which is comfortable about being limited by Form and does not crave for individual freedom because it is much more afraid of falling out of Form.

World War II was a turning point in the evolution of Gombrowicz's philosophy of freedom. Before 1939 he considered the value of freedom to be unquestionable and he did not talk about its dark sides. After the war Gombrowicz also began to see freedom as a tragic gift. In his play The Marriage he showed how an individual's pursuit of absolute freedom can turn into tyranny. The philosophy of freedom that he had formulated in Ferdydurke excluded such a possibility.

In order to understand the meaning of the philosophy of distancing oneself from Form, as articulated in Ferdydurke, one should find out whether Gombrowicz directed his moral guidelines from the 1930 s relating to practicing freedom only to people who lived in the interwar period, i.e. when the temperature of social tensions was moderate, or thought that it was also possible to distance oneself from Form in extreme situations, for example, during violent social conflicts, war, and occupation.
\end{abstract}

Gombrowicz uchodzi dość powszechnie za pisarza wolności. Ale jaka to była ta wolność w Ferdydurke i czy była to wolność ta sama co w Ślubie, Trans-Atlantyku, Pornografii, Kosmosie, Operetce i Dzienniku? Co się działo u Gombrowicza z pojmowaniem, portretowaniem i praktykowaniem wolności między rokiem 1933 a rokiem 1969, a więc między $P a$ miętnikiem z okresu dojrzewania a śmiercią w Vence?1.

Ontologia zniewolenia jest w Ferdydurke ${ }^{2}$ stokroć mocniejsza niż ontologia wolności. Przepaść między Józiem a społeczną większością jest

1 Por. T. Banaszak, Kilka uwag o pojęciu wolności u Gombrowicza, „Poznańskie Studia z Filozofii i Humanistyki” 1996, t. 3. Według autora modelem wolności spełnionej w pojęciu Gombrowicza była postać Iwony, księżniczki Burgunda. Ujęcie to nie bierze pod uwagę przemian, jakim podlegało myślenie Gombrowicza o wolności.

${ }^{2}$ W. Gombrowicz, Ferdydurke, [w:] Dzieła, t. II, red. nauk. J. Błoński, Kraków 1986. Dalej w tekście F i numer strony. 
całkowita i maksymalnie przez Gombrowicza hiperbolizowana. Ma ona charakter różnicy podstawowej. Większość - taką diagnozę stawiał młody Gombrowicz w latach trzydziestych - jest niezdolna do wolności i niezdolność ta wynika nie tyle z niezdolności moralnej, czyli nie jest wyłącznie efektem nieskutecznych starań, lecz ma charakter cechy niemal wrodzonej. Ani Zuta, ani Młodziak, ani Hurleccy, ani Syfon, ani Miętus nie są w stanie się zmienić. Można ich co najwyżej wytrącić z Formy, to znaczy pozbawić pewności wewnętrznej, ale nie można im pomóc w przeobrażeniu. I na ich wytrącaniu z Formy bohater Ferdydurke buduje swoją wolność. Jest to wolność demaskowania i odzierania z Formy, a nie wolność, która wspierałaby innych w dążeniu do wolności. Bo w innych, tak jak Gombrowicz w Ferdydurke przedstawiał społeczną większość, nie ma dążenia do indywidualnej wolności. Józio jest w tym dążeniu zupełnie sam. Tylko jemu jednemu uwiera Forma i tylko on jeden pojmuje, na czym polegają jej zniewalające mechanizmy, inni - tak to zostało przedstawione w Ferdydurke - nie mają o tym żadnego pojęcia. Po prostu o istnieniu Formy nie wiedzą. Nawet zbuntowany przeciw społecznym konwenansom Miętus jest sojusznikiem pozornym. On także - porwany marzeniem o parobku - nie wie, że jest ciasno zamknięty w formie „bra-atania się".

Fundamentem ruchu ku wolności jest w Ferdydurke uraz wyodrębnienia-odrzucenia, oparty na dotkliwej świadomości ontologicznej różnicy, jaka dzieli Józia od reszty ludzi w samym ich sposobie istnienia ${ }^{3}$. Jego napędza pragnienie Formy i strach przed Formą jako przed czymś, co może go zniekształcić i zniewolić, ich napędza strach przed wypadnięciem z Formy.

Józio wie, że aby się uratować spod nacisku Formy, ludzi można tylko napuszczać na siebie, zbijać w destrukcyjną „kupę”, z której wcale nie wyjdą ani lepsi, ani odmienieni. Czego nie napisał Gombrowicz w Ferdydurke? Ano tego, co dzieje się z Młodziakami, Zutą, Kopyrdą, Pimką po ich wepchnięciu przez Józia w międzyludzki kłąb, co oni robią dzień później, kim są, jak dalej żyją. To młodego Gombrowicza nie interesowało zupełnie. W ruchu ku wolności ważne jest skuteczne, manipulacyjne uderzenie w innych, które wytrąca ich z Formy, a mnie samego wyzwala z interakcyjnej zależności, a nie to, co z tego uderzenia później dla nich wynika. Tak jakby wolnym można było być tylko wobec bezbronnych i ośmieszonych, aranżując ich bezbronność i manipulując nią. Cele Józia to „kazić”, „nadziewać” (F 139), „zepsuć” (F 140), „zmusić”, „nadwątlić”

3 Z jednej strony Józio dąży do wyodrębnienia siebie z tłumu, co sprawia mu dumną satysfakcję, bo dzięki temu nie jest do innych podobny, $\mathrm{z}$ drugiej to wyodrębnienie odbiera także jako deprecjonujące i frustrujące, bo czuje, że inni go odrzucają jako odmieńca, co wyzwala w nim reakcje traumatyczno-nerwicowe. 
(F 143), „uczynić niewolnica moich fantazji” (F 143), uczynić „ofiarą kaprysu”, wepchnąć w potrzask (F 143), „dosięgnąć ich”, zepsuć „przemocą psychiczną" (F 147), „diabłem poszczuć" (F 147). Podlegać dominacji to być „złapanym za gardło” ( F 141), ale uwolnić się spod dominacji to „chwycić za gardło”. Symetryczność reagowania jest w Ferdydurke przedmiotem kpiny, ale i zasadą działania Józia.

Kulminacją strącenia innych w bezbronność jest w Ferdydurke naruszanie prywatności, które nie przedstawia dla Józia żadnego problemu. Dopaść innego w chwili, gdy jest wyłuskany z Formy, to znaczy bezbronny. Napis „Veni, vidi, vici” na ścianie łazienki ma poinformować ofiarę, że została z prywatności odarta zupełnie. Manipulowanie innymi poprzez strącanie w bezbronność i naruszanie cudzej prywatności jest w Ferdydurke formą budowania wolności własnej. Józio zresztą wcale nie wytrąca ludzi z Formy, by ich z niej wyzwolić, lecz - jak sam o tym mówi - strąca ich w formy niższe, estetycznie gorsze i poniżające. Pragnie „wytrącić z formy”, tak by stracili głowę (F 160), wpadając w „śmieszny żywioł brzydoty, ohydy, plugastwa".

Struktura fabularna Ferdydurke ma charakter antyretrospekcyjny, choć co jakiś czas powracają $\mathrm{w}$ niej retrospekcyjne migawki z dzieciństwa. Józio nie rozmyśla nad tym, co zrobił ludziom, od których się uwolnił. Nie powraca do sytuacji, które sam zaaranżował, żeby się od nich uwolnić. Ruch narracji jest linearny, słowa: Dalej! Naprzód! nadają kierunek opowiadaniu. Ludzie usunięci jako przeszkody w ruchu ku wolności są wymazywani z powieściowego świata, po prostu znikają z narracyjnego horyzontu - i pamięci bohatera - bez śladu. O dalszych ich losach nie dowiadujemy się niczego. O Syfonie wiemy, że się powiesił po tym, jak Miętus zgwałcił go przez uszy, ale inni? Co właściwie stało się z innymi? Strategia wymazywania nie jest żadną drugorzędną cechą struktury artystycznej Ferdydurke. Dla Józia istnieje pytanie: Kim będę? Czym mnie uczynią? Nie istnieje pytanie: Co ja uczynię (co uczyniłem) innym i czym oni się staną pod wpływem tego, co im uczynię (uczyniłem)? Józio mówi o „deformacjach uczynionych mi przez nich” (F 192), ale nigdy o deformacjach uczynionych im przez siebie, chociaż interakcyjna wizja Gombrowicza aż się prosiła o taką deformacyjno-manipulacyjną wzajemność!

W świetle ontologii bytu społecznego, tak jak ją rysował młody Gombrowicz w latach trzydziestych, nie istniała możliwość, by kiedykolwiek powstało społeczeństwo, które budowałoby i wspierało wolność w jednostce, bo społeczeństwo samo w sobie to przeciwieństwo wolności. Nawet jeśli zbiorowość, np. naród, walczy o wolność, w swoim wnętrzu ukrywa mechanizmy o wielkiej mocy zniewalające indywiduum, co młody Gombrowicz uważał za stan niezmienialny. Ból deformacji, płynący z uwięzienia w Formie, odczuwa tylko mniejszość. Większość, tak jak została 
przedstawiona w Ferdydurke, wcale nie cierpi z powodu uwięzienia w Formie, przeciwnie: cierpi właśnie wtedy, gdy jej się Forma rozsypuje i wymyka. Zupełnie inaczej niż Józio, który nie może wybaczyć większości, że świetnie się ona czuje w więzieniu Formy. Ta zadra tkwi w nim głęboko i napędza go do działania. Dla niego zamknięcie w Formie jest nieszczęściem, ograniczeniem, klęską. Dla większości bycie zamkniętym w Formie jest rodzajem codziennego szczęścia, które trzeba chronić przed prowokacjami zbuntowanego intruza. Paradoks Zuty, która jest przykładem takiego szczęścia, tkwi w tym, że ta dziewczyna, uwięziona bez reszty w Formie pensjonarki, jest równocześnie - jak to Gombrowicz przedstawiał - „pewna siebie, obojętna, sama dla siebie” (F 129), czyli rezygnując z wolności na rzecz pełnego utożsamienia się z Formą, osiągnęła stan istnienia pozarelacyjnego, wyzwolonego spod ciśnień interakcji, o którym Józio może tylko bezsilnie marzyćc !

Obrazy zagrożenia ze strony innych są w Ferdydurke przemożne. Kluczem do relacji z innymi (i samym sobą!) są słowa: „zjeżyłem się cały - poczułem człowieka jak pies psa” (F 15). Ta „psia” antropologia zagrożenia jest u Gombrowicza z gruntu antychrześcijańska. W świecie Ferdydurke idea budowania wspólnoty bliźnich nie wchodzi w rachubę. Społeczeństwo nigdy się taką wspólnotą nie stanie, ponieważ gra dominacji i zniewolenia jest jego podstawą. Fundamentem dynamiki fabularnej Ferdydurke jest resentyment prześladowania jednostki przez większość, hiperbolizacja stanów bycia ofiarą innych, zgniecenia, złapania w potrzask - i prawo do agresji obronnej. Znaczna część Ferdydurke jest pisana językiem przemocy zniewalającej i przemocy reaktywnej, uznawanej przez Józia za całkowicie usprawiedliwioną.

Ciągle słyszymy: „nie mogłem” - „musiałem”. Ten rytm wyznacza dynamikę życia wewnętrznego bohatera. Studium stanów przygniatającej niemożności i niezwalczonej konieczności jest specjalnością Gombrowicza i zajmuje dziewięćdziesiąt procent tekstu, co czyni jego pierwszą powieść prawdziwą antologią form zniewolenia. Zapewne Filidor i anty-Filidor wydostaliby się z matni symetrii i analogii, gdyby byli zdolni do dystansu wobec Formy. Rzecz w tym, że w latach trzydziestych Gombrowicz socjologię mieszał $\mathrm{z}$ ontologią, co w zasadniczy sposób rzutowało na jego koncepcję człowieka, wykluczając nadzieję na wyzwolenie. Forma, tak jak ją przedstawiał w Ferdydurke, jest bowiem tyleż wytworem Międzyludzkie-

\footnotetext{
${ }^{4}$ Paradoks Zuty polega na tym, że ta do szczętu zniewolona przez Formę dziewczyna jest - jakby powiedział Schulz o Biance - cudownie zgodna ze sobą (B. Schultz, Wiosna, [w:] tenże, Proza, Warszawa 1973, s. 159), doskonale - jakby do tego dodała Nałkowska zgodna ze swoim typem. Cierpienie pojawia się w niej nie z powodu uwięzienia w Formie, lecz w chwili, gdy Forma od niej odstaje - czyli dokładnie odwrotnie niż w przypadku Józia.
} 
go, co Pozaludzkiego. Zniewalające, symetryczne przeciwieństwo Filidora i anty-Filidora powstało - narrator Gombrowicza rzucał taką myśl mimochodem - nie tylko w wyniku działania praw życia społecznego, lecz i „w myśl Newtonowskiej zasady akcji i reakcji” (F 85), ponieważ - jak to zostało ironicznie podkreślone - każde zjawisko nie może nie wywołać w naturze „swego kontr-zjawiska" (F 85). Formułowane w partiach eseistycznych Ferdydurke wezwania do wolności i recepty na praktykowanie postawy dystansu wobec Formy zderzały się w partiach fabularnych $\mathrm{z}$ antywolnościową ontologią bytu społecznego i ontologią samej natury, której podstawą była Newtonowska konieczność przyrodnicza, najzupełniej zgodna $\mathrm{z}$ nienaprawialną ludzką skłonnością do symetrycznego reagowania. Tak jakby Gombrowicza pisarza bawiło równoczesne wzywanie do wolności i sztubackie podcinanie nóg tym, którzy chcieliby po nią sięgnąć. Cała druga część Ferdydurke jest fabularnym dowodem na nieskuteczność filozofii dystansu wobec Formy, do którego Gombrowicz $\mathrm{w}$ partiach eseistycznych energicznie zachęcał. Cokolwiek bowiem Józio by zrobił, dystansując się wobec wydarzeń, w jakich uczestniczy we dworze Hurleckich, do którego rzuciły go losy, musi się stać to, co się staje.

W latach trzydziestych Gombrowicz, rozmyślając nad fenomenem Formy, mieszał też socjologię $\mathrm{z}$ biologią. W końcu to nie przypadek, że w scenie bicia Walka po mordzie przez panów Hurleckich drastyczną sytuację międzyludzką mimochodem opisywał za pomocą analogii zoologicznej. „Tak indyk zaszczepia wróblowi indyka! Tak foksterier zaszczepia kundlowi kult foksteriera! Sowa sójce! Bawół psu!" (F 244). Rozmaite odmiany ludzi, podobnie jak rozmaite odmiany zwierząt, budują w stadzie hierarchię aktami przemocy, z czego mogło wynikać, że reguły międzyludzkiego istnienia są niezmienne, bo nie chodziło tylko o kulturowe normy zachowań, lecz o analogię podstawową, sugerującą zasadnicze podobieństwo między światem ludzi i zwierząt. Tak mogli myśleć o strukturze społecznego świata panowie Hurleccy, ale tak mógł myśleć o niej także sam narrator. W przestrzeń krytyki socjologicznej wdzierała się zoologiczna fizjonomika, która tę krytykę podważała od środka! Lud i panowie w Ferdydurke nie tylko dlatego tworzą odmienne, symetryczne wobec siebie światy, że podlegają społecznym mechanizmom Formy, które ich w odmienny sposób kształtują psychologicznie, lecz i dlatego, że są - co Gombrowicz podkreślał - inaczej ukształtowani w sensie biologicznym: mają inne ciała, ręce i nogi, „masywne, ciężkie”. „Łapy i stopy nie, gmin nie ma stóp - łapy i nogi, ogromna ilość łap i nóg [...] (F 247). W obliczu takiej przygniatającej anatomicznej różnicy, która rysowała się tutaj jak podstawa różnicy kulturowo-klasowej, zderzenie między odmiennymi typami psychofizycznymi musiało być zatem nieuchronne. 
Równie ciekawa jest rola bólu i krwi w Ferdydurke. Wybierając konwencję groteski pikarejskiej i poetykę powiastki filozoficznej w stylu Woltera, Gombrowicz zmieniał powieściowy świat w bezbolesny, wzorując obrazy międzyludzkich spięć i zderzeń na niemych filmach Chaplina. Każda osoba w Ferdydurke została przedstawiona tak, jakby miała ciało najzupełniej cielesne i równocześnie ciało czysto alegoryczne, złożone z osobnych, nacechowanych symbolicznymi znaczeniami części, właściwie niezdolne do odczuwania bólu. Słynna „anatomia Gombrowicza” taki właśnie miała charakter. U narratora Ferdydurke opisać człowieka znaczyło tyle, co opisać Formę, która nim włada, nie zaś psychofizyczną konkretność osoby. Nawet najzupełniej dosłowne „łapy” ludu w gombrowiczowskiej narracji zmieniały się w znak rozpoznawczy klasy społecznej i jej sposobu bycia. Kiedy się widzi człowieka jako abstrakcyjną Formę w ruchu, łatwiej w niego uderzyć i łatwiej nim manipulować. Józio działa z taką stanowczością wobec innych także dlatego, że - jak to odczuwa uderza nie tyle w ludzi, ile w samą Formę, czyli schematy zachowania $\mathrm{i}$ bycia kierujące ich zachowaniami, chociaż $\mathrm{w}$ istocie uderza $\mathrm{w}$ ludzi - i to boleśnie. W finale Józio z zemsty za infantylizowanie przez ciotkę wpycha ją w powszechne mordobicie - a niech zostanie pobita w kłębiącej się dworsko-chłopskiej „kupie”, co tylko rozbawia narratora, ale choć w opisie sytuacji ważną rolę odgrywa krew Walka bitego „po mordzie” przez panów i bijącego panów „po mordzie” (F 247), ból innego nie ma w istocie dla niego żadnego znaczenia, bo Forma każdej osoby jest i zarazem nie jest jej ciałem, rozbić ją to jakby rozdmuchnąć obłok, który spowija człowieka, kierując jego gestami. W oczach Józia ludzkie ciała są nie tyle somatyczne, ile semantyczne ${ }^{6}$. Ich fizyczny kształt jawi się jako groteskowa konstelacja gestów i znaków, którą można rozsypać jednym uderzeniem. Nikt w Ferdydurke nie ma ciała boleśnie odczuwającego ciosy. Żadnego bólu - tylko groteskowy efekt ogłuszenia, oślepienia, dezorientacji - jak w komedii slapstickowej: „Druzgot, taran i świeczki w oczach” (F 247).

Znacząca była także w Ferdydurke instrumentalizacja cierpienia zwierząt. W latach trzydziestych tortury muchy z oberwanymi skrzydłami, wsadzonej do damskiego pantofla, którym Józio chce „skazić” sterylną atmosferę sypialni Młodziaków, traktowane przez niego jako środek akcji samowyzwoleńczej, tylko młodego Gombrowicza rozśmieszały, czemu sprzyjała dystansująca konwencja groteskowej narracji. Ach, cóż sobie

5 Zob. J. Jarzębski, Anatomia Gombrowicza, „Teksty Drugie” 1972, nr 1.

6 O obrazach ciała u Gombrowicza zob. O. Kuhl, Ciało $i$ jego maskowanie u Gombrowicza, „Teksty Drugie” 1996, nr 1; M.P. Markowski, Czarny nurt. Gombrowicz. Świat. Literatura, Kraków 2004; M. Żółkoś, Ciało mówiq̨ce. „Iwona, księżniczka Burgunda” Witolda Gombrowicza, Gdańsk 2001. 
zawracać głowę jakimiś cierpieniami owada z powyrywanymi skrzydłami, skoro za pomocą jej „brudnej” męki można wyzwolić się spod przeklętej, obezwładniającej dominacji „nowoczesnych”. W latach sześćdziesiątych to samo cierpienie muchy zdychającej na lepie będzie przerażać Gombrowicza do tego stopnia, że zechce on mu poświęcić osobny dramat. Różnica między wrażliwością dawną i nową stanie się radykalna7.

Towarzyszyła tym desomatyzującym zabiegom, oczyszczającym świat przedstawiony z dosłowności fizycznego bólu, prawie kompletna głuchota młodego Gombrowicza na kolor i inne szczegóły materialnego wyglądu ludzi i rzeczy. Duże partie Ferdydurke są niemal „bezbarwne”. Żółte buciki Pimki, jego brązowy płaszcz, niebieskie ściany mieszkania Młodziaków, ale jaki właściwie kolor miało ubranie Józia? Nie substancje, lecz relacje Gombrowicza interesowały. Ten pisarz marzący o wolności, która miała się spełnić w konkretnej relacji face to face, w swojej powieści barwy prawie zupełnie ignorował albo traktował czysto alegorycznie. Zielony oznaczało przecież niedojrzały - to było najważniejsze... Ta alegoryzacja koloru miała później wybuchnąć w Trans-Atlantyku brawurową polemiką z mickiewiczowską zasadą widzę i opisuję. . W groteskowym świecie Ferdydurke pozbawionym substancji i koloru, w świecie tożsamości relacyjnej, narzucanej ludziom przez interakcje, w którym inni jawili się Józiowi jako ruchome schematy zachowań czy konstelacje cech typowych dla roli społecznej, w jaką zostali wepchnięci przez przypadek i manipulację „reżysera”, obronna przemoc uderzająca w tak ,zdematerializowane” obiekty stawała się łatwa, podobnie jak łatwa stawała się śmierć.

Koneksje między wolnością i śmiercią są w Ferdydurke zastanawiające. Znamienne, że moment zdobytej wolności Gombrowicz opisywał właśnie językiem śmierci. Nawet jeśli był to żart pikarejskiego narratora, nie był to żart bez znaczenia ${ }^{9}$. „Kiedy umiera w tobie wszystko, a nikt jeszcze nie zdążył urodzić się na nowo. O, warto żyć dla śmierci, by wiedzieć, że w nas umarło, że już nie ma, pusto i czczo, cicho i czysto [...] żadnego uczucia ani żadnego mechanizmu, nic, nic, nic..." (F 177). W Ferdydurke stanem wolności jest zupełny brak wszelkich doznań, uczuciowa pustka i brak pamięci. Wolność jako „zobojętnienie błogie” (F 176), bez jednego wspomnienia, chwila całkowitego wymazania z pamięci tego, w czym się uczestniczyło, tak jakby między wolnością i pamięcią była ontologiczna sprzeczność nie do usunięcia. Nic dziwnego, że nar-

7 Por. A. Czyż, Cierpienie i Gombrowicz, „Ogród” 1992, nr 2.

8 Zob. S. Chwin, „Trans-Atlantyk” wobec „Pana Tadeusza”, „Pamiętnik Literacki” $1975, \mathrm{nr} 4$.

9 O czarnym humorze w twórczości Gombrowicza zob. T. Bocheński, Czarny humor w twórczości Witkacego, Gombrowicza, Schulza. Lata trzydzieste, Kraków 2005. 
racja w Ferdydurke biegła pośpiesznym rytmem - bez pamięciowych nawrotów i spowalniających ją detalicznych opisów postaci, przedstawianych jako pełnokrwiste, powieściowe „charaktery”10. Początkiem Ferdydurke jest silnie doznawany przez bohatera lęk nieistnienia, strach przed nie-byciem, żarliwa chęć jednostkowego samourzeczywistnienia. $\mathrm{Ku}$ wolności pcha Józia lęk przed unicestwiającym spojrzeniem Innego (np. ciotki Hurleckiej: „tonę w dobroci cioci [...] a zresztą, czy istnieję dla niej?", F 197), a więc pragnienie umocnienia własnego bytu, jego zintensyfikowania, ale chwila osiągniętej wolności opisywana była anihilacyjnym refrenem „nic, nic, nic”. Stan wolności to trwający „setny ułamek sekundy" moment wyzwalającego samounicestwienia (F 177), tak jakby wolność była nagłą przerwą $\mathrm{w}$ istnieniu, małą śmiercią ${ }^{11}$. „Odchodzić idąc, iść odchodząc i nie czuć nawet wspomnienia. Zobojętnienie błogie! Bez wspomnienia!" (F 176) - taki stan osiąga Józio po zaaranżowaniu wzajemnego mordobicia u Młodziaków. Zdolność do wolności zaczyna się $\mathrm{u}$ niego zresztą od zdolności do wypowiedzenia rozluźniających słów: „mnie wszystko jedno...” (F 136). Kto takie słowa wypowiada, wyzwala się - choćby tylko na chwilę - z piekła interakcji, uwolniony od dręczącego starania, by w oczach innych wypaść jak najlepiej.

Bohater Gombrowicza walczy o swoją suwerenność śmiechem, ale nie jest w stanie zarazić wyzwalającym śmiechem tych, z którymi walczy ${ }^{12}$. Zresztą wcale do tego nie dąży. Zasadą działania Józia w Ferdydurke jest: niech gwałt się gwałtem odciska. Ależ to w gruncie rzeczy bardzo dobrze - daje do zrozumienia Józio - że wszyscy, z którymi mam do czynienia, są tak zapeklowani w Formie, choć pewnie są przez to okropni, ale właśnie dlatego, że są zapeklowani, można w nich uderzyć w rewanżu za własną bezsilność i odmienność. A wieszaj się Syfonie na wieszaku, bo na to zasłużyłeś, skoro podczas pojedynku na miny zachowywałeś się jak marionetka wśród marionetek. Lekceważący kalambur „wieszać się na wieszaku", zmieniający powagę samobójstwa w slapstickowy gag z filmu Chaplina, tylko potwierdzał taką intencję. Śmiech majeutyczny, wspierający w ludziach chęć wyzwolenia się z Formy, wspomagający ich w dążeniu do wolności, rozładowujący zamknięte koło akcji i reakcji, uwalniający od przymusu symetrycznego reagowania uderzeniem na uderzenie, miał się pojawić się u Gombrowicza znacznie później.

Przejście od strategii rewanżu do strategii śmiechu majeutycznego przypada u Gombrowicza na czas pisania Trans-Atlantyku i wiąże się

10 Zob. A. Zawadzki, „Ferdydurke” Witolda Gombrowicza wobec tradycji powieści pikarejskiej, „Pamiętnik Literacki” 1994, z. 4.

11 Por. A. Fiut, Gombrowicza pląs ze śmiercia, „Teatr” 1997, nr 10.

12 Zob. B. Zielińska, Śmiech Gombrowicza, „Ruch Literacki” 1987, z. 4-5. 
z ofertą Giedroycia, który osamotnionemu pisarzowi z Argentyny dał platformę publiczną do głoszenia poglądów. Wtedy to Gombrowicz wszedł w rolę - jak sam to określał - Mojżesza wyprowadzającego Polskę i całą ludzkość z więzienia Formy. Wcześniej - jako autor Ferdydurke - nie miał takich ambicji. Żadnym Mojżeszem tłumów być nie zamierzał. I nie narodową Formą Polską ${ }^{13}$ się przejmował, tylko Formą bliskiej przestrzeni międzyludzkiego obcowania. Przede wszystkim starał się wypracować oryginalny kształt i sposób praktykowania własnej prywatnej wolności w przestrzeni bezpośrednich interakcji, bo choć $\mathrm{w}$ partiach eseistycznych wzywał czytelników do powszechnego praktykowania ferdydurkizmu, dawał do zrozumienia, że społeczeństwo składające się wyłącznie $\mathrm{z}$ samych ferdydurkistów $\mathrm{w}$ realnej rzeczywistości jest raczej mało prawdopodobne. Takie społeczeństwo pewnie nie przetrwałoby nawet tygodnia.

Antropologiczna perspektywa Ferdydurke umacniała podstawowy podział ludzkiego świata na pojedynczych partyzantów wolności i nieuzdrawialną większość, która dobrze się czuje właśnie dlatego, że jest mocno zrośnięta ze swoją Formą. W Ferdydurke młody Gombrowicz dawał do zrozumienia, że wolność jest tylko rarytasem dla nielicznych, którzy dotkliwie odczuwają, że Forma ich uwiera, a społeczny bios większości, podtrzymywany przez schematy zachowań, uderzony przez zbuntowanych ferdydurkistów, odrasta szybko po każdym skaleczeniu, niezwalczony. I w Ferdydurke oglądamy kilka takich skaleczeń, zadanych przez Józia, po których ciało społeczne - jak możemy się domyślać - zrasta się bez śladu. Po wypadach partyzantów wolności zbiorowość powraca do stanu homeostazy, z którego nic jej na dłużej nie jest w stanie wytrącić. Partyzantom wolności pozostaje tylko szukać sojuszników wśród duchów podobnych sobie, zresztą zupełnie nielicznych.

Melodią fabuły Ferdydurke - inaczej niż w partiach eseistycznych! - jest wolność przede wszystkim dla mnie, a dopiero potem dla innych. W finałowych scenach dążący do wolności Józio zmienia młodą kobietę, rezydentkę szlacheckiego dworu, w przedmiot, by ułatwić sobie wyjście z niezręcznej sytuacji i jeszcze szydzi z jej zupełnej bezbronności, na dodatek z pretensjami, że to ona jego - biedaka - zniewala! Ale przecież to on sam, nikt inny, wpycha ją w formę panny porwanej z dworu, by użyć dla własnych celów, nie czując przy tym do niej nic. Prawie w całej Ferdydurke Józio bierze pod uwagę wyłącznie swoją sprawę: innych traktuje jako rzeczy, które bądź zawadzają i zniewalają go, bądź których może użyć w walce z Formą. Co Józio zrobi z Zosią w powieściowej po-akcji,

13 Zob. L. Neuger, Polskość jako cel, „Teksty Drugie” 1991, nr 1-2; S. Chwin, Gombrowicz $i$ „Forma Polska”, posłowie, [w:] W. Gombrowicz, Trans-Atlantyk, Kraków 2005. 
kiedy już - jak zapowiada - dojedzie z nią do Warszawy? Ależ z punktu widzenia powieściowego narratora to sprawa bez znaczenia! Zawracać sobie głowę jakąś Zosią, która przecież właściwie tak naprawdę wcale nie jest żywą kobietą, tylko męczącą konstelacją stereotypów? Przecież to on jest zniewolony, to on jest jej ofiarą, on ma prawo się od niej uwolnić. To prawo w Ferdydurke jest definiowane serią czasowników: oderwać się, odsunąć, uderzyć, rozbić (F 254). Ponieważ każdy człowiek jest zagrożeniem, pozostaje tylko przemieszczać się wśród ludzi - naprzód! naprzód! - uciekając linearnym zygzakiem fabuły z niewygodnych sytuacji. Tak właśnie podstawową figurą wolności w świecie młodego Gombrowicza staje się figura ucieczki14. Jesteś z kimś? Wzywaj trzeciego człowieka, by cię wyzwolił z uwierającego związku z innym. I w finale Ferdydurke Gombrowicz dawał swoją definicję życia ku wolności: uciekać od ludzi w innych ludzi. Formułą wolności jest tutaj nie wiązać się z nikim, wymykać się, porzucać bez żadnych skrupułów - „pędzić, pędzić przez całą ludzkość" (F 255). Strach przed trwalszym związkiem z drugim człowiekiem był tłem przygody młodego Gombrowicza z wolnością. Resentyment bycia prześladowanym przez większość - i przez osoby dominujące, przede wszystkim przypominające „archetyp” ojca - napędzał całą maszynerię narracji. To ja jestem ofiarą innych, mam więc prawo uciekać, bronić się, wymykać, zrywać wszelkie więzy. Jeśli jednak prawdziwa sztuka życia polega właśnie na tym, by umieć trwale być z kimś innym na dłużej, a przy tym umieć zachować wolność? Młody Gombrowicz, jak o tym świadczą jego imaginacyjne przygody opisane w Ferdydurke, $\mathrm{w}$ taką możliwość zupełnie nie wierzył. Czy uwierzył w nią w latach sześćdziesiątych, kiedy - stary, dojrzały, słaby - zdecydował się być na dłużej z Ritą 15 ? Ruch ku wolności w Ferdydurke jawił się młodemu Gombrowiczowi jako jednoznacznie pozytywny. To przecież oczywiste - mam prawo do wolności! Problemem Józia jest to, że wolności nie jesteśmy w stanie osiągnąć do końca, ale nie to, że w samej wolności tkwi jakaś mroczna, wewnętrzna skaza, której nie da się od niej oddzielić. Ona sama, wolność - jako wartość i cel dążenia - jest poza wszelkim podejrzeniem. Dlatego Ślub od Ferdydurke dzielą lata świetlne. Jakby oba te teksty - jeśli chodzi o filozofię wolności - zostały napisane przez dwie różne osoby.

14 Podobnie w Historii. Mówił tutaj Witold: „Jedyne, co może nas zbawić, / To ucieczka z tego więzienia / W jakim jesteśmy zamknięci. / UCIEKAJ! [...] WYŁAMUJ! UCHYLAJ SIĘ!” (W. Gombrowicz, Historia, Teatr Szwedzka 2/4, s. 44. Zob. J. Jarzębski, Gombrowicz: ucieczka z rodzinnego domu, „Miesięcznik Literacki” 1988, nr 2-3.

15 Por. R. Gombrowicz, 20 lat byłam niewolnica, rozm. H. Baltyn, „Życie Warszawy” 1993, nr 135, dod. s. 6-7; Married to the Modernist. Rita Gombrowicz remember Witold, rozm. G. Indiana, „New Horizon” 1996, t. 21, nr 9-10. 
Wstrząs wojenny przeorganizował myślenie Gombrowicza o wolności do samych podstaw. Taka jest moja teza. Cała twórczość Gombrowicza jeśli chodzi o jego rozumienie wolności - rozpada się na dwie niepodobne do siebie części. Nie jest kontynuacją idei z lat trzydziestych czy ich płynną ewolucją, lecz raczej serią zerwań i zmian sposobu myślenia. $\mathrm{O}$ żadnej ciągłości nie było tu mowy. Cezurą stała się wojna. I Ferdydurke - inaczej niż sądził Jan Błoński ${ }^{16}$ - nie była wcale zalążkowym projektem wszystkiego, co Gombrowicz miał napisać później. Znaczna część jego twórczości powojennej była - przynajmniej jeśli chodzi o kierunek refleksji nad wolnością - właśnie antyferdydurkiczna. Jako filozof wolności Gombrowicz zmieniał się, odchodząc od Ferdydurke. Wystarczy tytułem przykładu porównać dwa ujęcia tematu pojedynku w Ferdydurke i w Trans-Atlantyku, a także obraz samobójstwa w Ferdydurke i w Ślubie. Różnice są uderzające. W Ferdydurke Gombrowicz bawił się widokiem wzajemnej destrukcji Filidora i anty-Filidora strzelających do siebie i swoich żon. Właśnie skuteczne strzały były warunkiem dobrej zabawy, odpadające palce, nosy i uszy. Narrator napuszczał na siebie pojedynkowiczów, doprowadzając ich do ostateczności. Zamykał ich w kleszczach symetrycznego reagowania po to, by ich skompromitować, lecz nie po to, by ich wyzwolić! Groteskowo zhiperbolizowana reguła symetrii i analogii miała wykazać swoją absurdalność i ośmieszyć głupotę mędrców zamkniętych w pułapce wzajemnych odbić. On sam unosił się ponad tę pułapkę, w sztubackiej satysfakcji, że mechanizmom symetrii wcale nie podlega, bo przeniknął ich zasadę na wylot. I bawił się obrazami groteskowej destrukcji cudzego ciała, które nie było w stanie wydostać się z zatrzaśniętej klatki akcji i reakcji ${ }^{17}$. W Trans-Atlantyku najważniejsza była idea pojedynku bez kul w lufach. Symetrycznie reagujący, stojący naprzeciw siebie w śmiertelnym starciu Tomasz i Gonzalo strzelali do siebie - ku radości Gombrowicza i czytelników - samym tylko prochem. Kleszcze symetrii rozluźniały się i rozpadały w uzdrawiającym śmiechu. W Trans-Atlantyku demoniczny Gonzalo w swoim anarchicznym dążeniu do wolności stwarzał sytuację, w której miała polać się krew, Syn miał zabić Ojca w imię wyzwalającej się Synczyzny, ale powojenny Gombrowicz wycofywał się z prowokacyjnej ostateczności takiego rozwiązania i krwawy finał powieści rozładowywał wybuchem majeutycznego śmiechu ${ }^{18}$. Na ta-

${ }^{16}$ Zob. J. Błoński, Forma, śmiech i rzeczy ostateczne. Studia o Gombrowiczu, Kraków 2003.

17 Zob. B. Zielińska, Staczanie się $w$ ciało. Gombrowicz i cielesność, „Ruch Literacki” 1994, nr 1-2.

18 Zob. J. Margolin, Witolda Gombrowicza teatr marionetek (o powieści „Trans-Atlantyk”), „Teksty Drugie” 1998, nr 3. 
kie rozwiązania w Ferdydurke nie było jeszcze miejsca. Pojedynek na miny musiał się skończyć śmiercią Syfona.

Podobnie z tematem samobójstwa. Wpędzenie w samobójstwo Syfona przez Miętusa w latach trzydziestych tylko bawiło Gombrowicza. Wpędzenie w samobójstwo Władzia przez Henryka nabierało powagi zbrodni. Miętus tę śmierć - której był pośrednim sprawcą - ignorował. Gombrowicz nawet o niej w dalszych częściach Ferdydurke nie wspomina. Była ona drobnym, nic nieznaczącym epizodem. W Ślubie samobójstwo Władzia stawało się sprawą kluczową dla całej wymowy dramatu. Henryk najpierw zabawiał się z Władziem, zachęcając, by ten z dystansem wyrecytował formułę zgody na własną śmierć. Korzystając ze swojej nieograniczonej wolności, eksperymentował słowami na duszy Innego, ciekaw, co z tego eksperymentu wyniknie, jeśli „dworzanin” wypowie podsuwaną $\mathrm{mu}$ formułę, jak zadziałają słowa wypowiedziane $\mathrm{z}$ dystansem, czy zaowocują czynem. Kiedy Władzio się zabija, a dwór rozstępuje się, odsłaniając ciało samobójcy, Henryk może powiedzieć z pychą władcy autorytarnego, że to na jego rozkaz, że w swojej potędze to on sam jest sprawcą $\mathrm{i}$ „autorem” tej śmierci, ale może też z zupełnym spokojem powiedzieć coś dokładnie przeciwnego - że nie ma z tą śmiercią nic wspólnego, bo przecież czy nie poprosił Władzia tylko o wypowiedzenie kilku słów z dystansem? Henryk - człowiek pożądający nieograniczonej wolności - robi z innymi, co mu się żywnie podoba w poczuciu, że nie jest za nic odpowiedzialny. Niosą go przecież nie tylko własne ambicje, pożądania i lęki, ale też samoprzekształcające się poza jego wolą wiry interakcyjnych napięć i zawęźleń. Bo rzeczywiście w Ślubie nie ma pewności, czy ktokolwiek jest za cokolwiek odpowiedzialny. Głównym odpowiedzialnym jest Forma. To ona - a nie tylko ludzkie intencje i pragnienia - decyduje o wszystkim. Ale w finale Henryk, choć o tym wie, bierze na siebie winę, uznaje śmierć Władzia za czyn własny, co może znaczyć, że z królestwa dowolności przechodzi do królestwa winy tragicznej19. Poczucie winy tragicznej nie mieściło się zupełnie w świecie Ferdydurke. Nic podobnego nie przyszłoby do głowy Miętusowi po śmierci Syfona.

W Ferdydurke Gombrowicz pokazywał, jak można walczyć o indywidualną wolność w bezpośredniej przestrzeni interakcji. Dawał popisowy przegląd rozmaitych wolnościowych strategii. W Ślubie odkrywał wolność jako dar dwuznaczny, niebezpieczny, wymagający najwyższej uwagi moralnej. I podkreślał, że ceną wolności własnej, posuniętej do końca, bywa cudze zniewolenie i śmierć. Że od absolutnej wolności do absolutne-

19 Zob. J. Błoński, Gombrowicz jako tragediopisarz, „Dialog” 1990, nr 2.

Stefan Chwin


go zniewolenia tylko jeden $\mathrm{krok}^{20}$. O niczym takim nie było mowy w Ferdydurke.

Henryk ze Ślubu chce osiągnąć wolność poprzez opanowanie i ubezbronnienie innych, a więc postępuje podobnie jak Józio, ale w jakimś momencie - inaczej niż bohater Ferdydurke - odkrywa, że w samym ruchu ku wolności tkwi jakiś mroczny pierwiastek, który może go porwać i unieść w ciemność. W Ferdydurke Syfon wiesza się na wieszaku - żeby było zabawniej, żeby było śmieszniej. W Ślubie Henryk po śmierci Władzia aresztuje samego siebie, co czyni - to jedna z możliwych interpretacji - w tragicznym geście samoukarania. Jako autor Ferdydurke młody Gombrowicz nie wiedział jeszcze, czym jest tragiczny dar wolności. Jego refleksja nad wolnością nie biegła w tym kierunku. Przed wojną narzekał na brak wolności i wieczne trudności w jej osiąganiu. Po wojnie dostrzegł, jak radykalny ruch w stronę wolności przeradza wolność w autorytaryzm. Dlatego od Ślubu do Tanga Mrożka nie tak znów daleko, bo sprawa była podobna.

Lecz jaki właściwie był projekt etyczny wpisany w Ferdydurke? Czy filozofia wolności, którą Gombrowicz rysował w latach trzydziestych, była w stanie sprostać ostatecznej próbie w sytuacjach ekstremalnych wojennego czasu? Czy wpisany w Ferdydurke projekt postawy wobec życia mógł stanowić oparcie dla ludzi, którzy stanęli w obliczu doświadczeń ekstremalnych, np. dostali się w ręce NKWD i Gestapo? Czy ów ferdydurkiczny projekt był projektem uniwersalnym na wszystkie możliwe sytuacje życia, czy raczej był projektem na określony tylko czas, moment historyczny, stan społeczeństwa?

W Ferdydurke kpił Gombrowicz z tych, którzy uważają płacz kobiety na pogrzebie męża za autentyczny, a więc wyrastający ze zbolałego serca. „[...] wam się wydaje - konstatował ironicznie - że to uczucia [...] rządzą naszym zachowaniem” (F 78). Sądzicie, że „wdowa idąca za trumną męża, do rozpuku szlocha” dlatego, że „ciężko odczuwa swą stratę” (F 78)? Wynikało stąd, że płacz kobiety na pogrzebie męża jest efektem ulegania Formie, że wcale nie bierze się ze stanu jej uczuć, że kobieta na pogrzebie męża płacze, ulegając regułom pogrzebowego obyczaju, płacze ze względu na innych, ze względu na pogrzebową publiczność, a zatem jest w swoim pogrzebowym płaczu nieautentyczna. Ale w jaki sposób na pogrzebie miałaby okazać swoją autentyczność zgodnie z etycznymi zaleceniami Gombrowicza: „Przestań się utożsamiać z tym, co cię określa. Uchyl się wszelkiemu wyrazowi. Nie ufaj własnym słowom. Nie dowierzaj uczuciom.

20 Por. M. Delaperriere, Kościót międzyludzki i absurd totalitarny w teatrze Gombrowicza, „Teksty Drugie” 2002, nr 3; S. Chwin, Gombrowicz i Niemcy, [w:] Gombrowicz nasz wspótczesny, red. J. Jarzębski, Kraków 2012. 
Wycofaj się z tego, czym jesteś na zewnątrz. Niech cię ogarnie lęk przed wszelkim uzewnętrznieniem. Zamiast ryczeć - ja to czuję - powiedz sobie z pokora - mnie się to czuje" 21 .

$\mathrm{Na}$ paręnaście miesięcy przed wybuchem wojny, klęską Warszawy i powstaniem obozu koncentracyjnego w Auschwitz pisał Gombrowicz: „nie to jest najważniejsze: umierać za idee” i „wiary”, „ale to: wycofać się o krok i zdobyć dystans do wszystkiego”, co „wydarza się z nami” (F 83). Jak jednak miałby zastosować w praktyce te zalecenia Gombrowicza człowiek, który zgodnie ze swoją wiarą, a więc najgłębszymi przekonaniami religijnymi, decydowałby się oddać życie za innego? Jak w takiej ekstremalnej sytuacji miałby wcielać projekt etyczny dystansu wobec Formy wpisany w Ferdydurke? Jak miałby „zdobyć dystans do wszystkiego"? I na czym miałoby właściwie polegać zalecane przez Gombrowicza jego „wycofanie się o krok”? Matka każdego z nas - pisał Gombrowicz powinna „wpajać w syna nie tylko zasady, lecz także zdolność umykania im, iżby go nie przydusiły (F 83)". Jak jednak człowiek, który decydowałby się oddać życie za innych, miałby okazać „zdolność umykania” zasadom, „iżby go nie przydusiły”? Czy oddając życie za innego, dawałby dowód, że zasady go jednak „przydusiły”, to znaczy uległ Formie, tracąc prawdziwą wolność i autentyczność? I jakie skutki wywołałoby, gdyby ktoś, kto kieruje się imperatywem poświęcenia życia w imię wiary, powiedział sobie: „zamiast ryczeć «Ja w to wierzę - ja to czuję - ja w to wierzę»" - mówię sobie „z pokorą «Mnie się w to wierzy - mnie się to czuje - mnie się to powiedziało, uczyniło»" (F 83). I gdyby ten człowiek był kapłanem, na czym by mogło polegać to, że powinien on - jak pisał Gombrowicz - „zlęknąć się ołtarza” (F 83)? Czy kapłan, który w godzinie ostatecznej próby „zlęknąłby się ołtarza”, miałby w sobie siłę ofiarowania siebie za innych? Gdyby np. w godzinie ostatecznej próby Maksymilian Kolbe zgodnie z tymi słowami uwierzył, że wcale nie wierzy, tylko mu się wierzy, czy byłby wówczas w stanie oddać życie za życie Innego? Chodzi o sprawę zasadniczą. O sens i ograniczenia projektu etycznego wpisanego w Ferdydurke. Jak ten sens i te ograniczenia badać?

Jako narrator Ferdydurke Gombrowicz w latach trzydziestych podawał swoje etyczne zalecenia w lekkiej, ironicznej formie, kamuflując czy osłabiając ich stanowczość i ostrość. Jeśli jednak wyjmiemy je z tekstu macierzystego i umieścimy w sytuacjach alternatywnych, podobnych do tych, które on sam w swojej twórczości z upodobaniem konstruował ${ }^{22}$, być

21 Sformułowania te są zwięzłą parafrazą zaleceń Gombrowicza podanych w partii eseistycznej Ferdydurke (F 78-83).

$22 \mathrm{Na}$ przykład w dramacie Historia, gdzie rysował wyobrażone sytuacje, w których rozmawiał z cesarzem Niemiec Wilhelmem II, Wieniawą-Długoszowskim czy marszałkiem Piłsudskim, przedstawiając im swoje zalecenia etyczne. 
może odsłoni się ich wyraźniejszy sens. Otóż równie prowokacyjnych zaleceń wolnościowych, utrzymanych w lekkim tonie narracji groteskowej, w twórczości powojennej Gombrowicza już nie znajdziemy. W tej twórczości zmienia się samo rozumienie siły słowa i pojmowanie odpowiedzialności za słowo, zmienia się także ocena ludzkiego ruchu ku wolności. Po wojnie Gombrowicz nie skierował już do nikogo, kto znalazłby się w sytuacji ekstremalnej, zdania: Wierzysz? Tobie się tylko tak zdaje, że wierzysz. Naprawdę twoja wiara jest tylko ruchem znaczeń w głowie. Grą pojęć. Skutkiem oddziaływania na ciebie mechanizmów Formy. Niczym więcej. Nawet w Pornografii nie posunął się tak daleko, chociaż ironicznie przedstawił wiarę jako system zachowań determinowanych przez społeczne interakcje. Chciał, by dystans wobec Formy bronił ludzi przed popadaniem w rozmaite fanatyzmy, nigdy jednak otwarcie nie zakwestionował np. psychologicznej autentyczności przekonań religijnych osób wierzących, co robił w Ferdydurke, gdzie przedstawiał religię jako formę społecznego istnienia ludzi, konwencję, styl bycia, a więc efekt interakcji. Stał się też dużo bardziej wrażliwy na ból odczuwany przez innych (nie mówiąc już o bólu zwierząt) i w swojej etyce bardziej „chrześcijański” niż przed wojną, chociaż w Boga nie wierzył do końca. Pisząc Ferdydurke, nie miał w sobie zbyt wiele „chrześcijańskiej” empatii dla bliźnich. Bliżej mu było do Chaplina niż do Jezusa. Po wojnie tę empatię przeniósł nie tyle do powieści - np. Kosmos jest pod tym względem dość chłodny - ile do Dziennika i dramatów.

Cała Ferdydurke była wyrazem młodzieńczego ducha Gombrowicza, ale była też wyrazem ducha Polski międzywojennej, swobodnej, rozluźnionej, która jeszcze nie poznała na sobie dotknięcia wojny i żelaznego uścisku totalitaryzmów. Gombrowiczowska filozofia wolności, która organizowała jej fabułę, wyrastała $\mathrm{z}$ tego ducha, przez co kompletnie rozmijała się z nadciągającą historią. Przed wielką próbą koszmaru wojny i okupacji pisał Gombrowicz: „Niezadługo sobie zdamy sobie sprawę, że już to nie jest najważniejsze: umierać za idee” i „wiary”, ale „zdobyć dystans" wobec idei i wiar. Czy takie zalecenie powtórzyłby w latach czterdziestych wobec ludzi żyjących w okupacyjnej Warszawie?

Filozofia wolności w Ferdydurke była filozofią wolności na czas umiarkowanej presji, czas letnich temperatur społecznego życia. Czy ta filozofia mogła dać oparcie w czasach, gdy historia rozżarza się do czerwoności? Literatura czasów wojny i okupacji, a także historia okupacyjnego obyczaju dowodzą jednak, że tak. Bez wolnościowego ducha Ferdydurke nie byłoby Trzebińskiego dramaturga i Misterium niedzielnego Gajcego, i Andrzejewskiego nowelisty, i antypowstańczej ironii Miłosza. Jak dowodzą wspomnienia tego ostatniego, spisane w Rodzinnej Europie, ferdydurkiczny humor pomagał Polakom przetrwać w wielu sytuacjach 
okupacyjnych. Okupacyjna codzienność byłaby bez niego trudna do zniesienia. Ale w sytuacjach ekstremalnych? Czy wtedy postawa gombrowiczowska wzmacniała czy osłabiała? Jak mogłaby wyglądać choćby śmierć $\mathrm{w}$ powstaniu warszawskim, gdyby miała być zgodna $\mathrm{z}$ gombrowiczowskim zaleceniem dystansu wobec Formy? I czy taką śmiercią umierano w Warszawie w 1944 roku? Baczyński w duchu dystansu wobec Formy napisał swoje młodzieńcze opowiadania, ale na śmierć w swojej poezji przygotowywał się w zgoła innym, właśnie stanowczo antygombrowiczowskim duchu, zapatrzony nie tyle w dystans wobec Formy, ile w mistycznych rycerzy Słowackiego. Bardzo byłoby ciekawe wyobrazić sobie jego spotkanie z Gombrowiczem na placu Zamkowym w przeddzień wybuchu powstania. Jak by takie spotkanie wyglądało? O czym by rozmawiali? Co by sobie powiedzieli? I jakie miejsce w tej rozmowie zająłby etyczny projekt ferdydurkizmu? Czy wpłynąłby jakoś na Baczyńskiego? I czy historyk literatury od czasu do czasu nie powinien pozwalać sobie na rysowanie takich hipotetycznych sytuacji, by bardziej zbliżyć się do ducha dawnych tekstów, ożywiając historycznoliteracki dyskurs, nawet jeśli może to budzić rozmaite opory?

Oczywiście twierdzić, że projekt etyczny Gombrowicza z lat trzydziestych był sformułowany na czas życia w historii o umiarkowanej temperaturze, nie znaczy wcale ten projekt dezawuować. Nie to było moim zadaniem. W końcu nie wszyscy pisarze muszą być Baczyńskimi czy Conradami. Sam zresztą Gombrowicz w Dziennikach otwarcie wyznawał, polemizując z egzystencjalizmem Sartre'a, że jest człowiekiem umiarkowanych temperatur i pragnie takim człowiekiem pozostaće ${ }^{23}$. Nie zawsze jednak zastanawiamy się, co to właściwie znaczyło być ferdydurkistą czy człowiekiem umiarkowanych temperatur. Bo może, aby to zrozumieć, trzeba wyobrazić sobie ferdydurkistę i człowieka umiarkowanych temperatur we wszystkich możliwych sytuacjach życia? Projekt etyczny Ferdydurke pragnął zmiękczać $\mathrm{w}$ ludziach zdolność do wszelkiego fanaty$\mathrm{zmu}^{24}$. Zawierał $\mathrm{w}$ sobie jednak także możliwość osłabienia wszelkiej wiary, nie tylko wiary fanatycznej. Sam Gombrowicz dobrze zdawał sobie z tego sprawę i pewnie dlatego w Dzienniku stwierdził, że mimo wszystko chce pozostać po stronie Boga, nawet jeśli w Boga nie wierzy. I nie napisał wcale, jak to ujmował w Ferdydurke: „mnie się w Boga nie wierzy”, tylko informował czytelnika otwarcie o swojej niewierze, wcale nie uważając jej za jakiś fakt interakcyjny, a więc stan ducha wymuszony przez

${ }^{23}$ Por. błyskotliwą analizę finału Trans-Atlantyku jako narracyjnej gry rozładowującej napięcie zbrodni; J. Jarzębski, Gra w Gombrowicza, Warszawa 1982, s. 416-435.

${ }^{24} \mathrm{O}$ funkcjach antyfanatycznych śmiechu zob. R. Nycz, Gest śmiechu. Z przemian świadomości literackiej początków XX wieku, „Pamiętnik Literacki” 1997, z. 4. 
międzyludzkie napięcia. W tym punkcie był już daleko od młodzieńczej powieści, w której nie było miejsca na wyznanie: nawet jeśli nie ma Boga, będę po stronie Boga. Duch Ferdydurke był radykalnie świecki25. Nie brał pod uwagę możliwości jakiegoś „chrześcijaństwa bez Boga”. W latach trzydziestych Gombrowicz nie dostrzegał jeszcze problemów, przed którymi miał stanąć po wojnie.

Dla historyka literatury równie ważne jest jednak jeszcze inne pytanie. Jak to się stało, że właśnie dzięki tym wszystkim młodzieńczym „grzechom” przeciwko wolności, z których Gombrowicz wyzwolił się po traumatycznym doświadczeniu wojny, Ferdydurke - jak mnie niegdyś przekonywał nieodżałowany Jan Błoński - jest najlepszą rzeczą, jaką Gombrowicz kiedykolwiek napisał? Bo jeśli to właśnie dzięki tym „grzechom" jako autor Ferdydurke miał najlepiej ustawiony głos, najbardziej panował na składnią, najzręczniej prowadził narrację ze sztubackim wigorem, młodzieńczą jednostronnością i bezczelnością, która sprzyja wyobraźni, nie oglądając się na cokolwiek? I tego sukcesu z młodości właśnie dlatego, że w Ślubie, Trans-Atlantyku czy Kosmosie myślał o wolności dużo głębiej - już nigdy nie powtórzył?

25 O złożoności ateizmu Gombrowicza zob. J. Jarzębski, Bóg ateistów: Schulz, Gombrowicz, Lem, „Znak” 1997, nr 2. 
